the US Public Health Service. Actinomycin $D$ was supplied by Merck, Sharpe and Dohme.

Stuart J. Coward

Department of Zoology,

University of Georgia.

Athens, Georgia 30601.

Received June 24, 1968.

1 Reich, E., Science, 143, 684 (1964).

2 Ursprung, H., Ann. Rev. Genet., 1, 139 (1967).

${ }^{3}$ Gabriel, A., in Regeneration in Animals and Related Problems (edit. by Kiortsis, V., and Trampuseh, H. A. L.) (North Holland, Amsterdam,
1965).

${ }^{4}$ Coward, S. J., and Flickinger, R. A., Growth, 29, 151 (1965).

${ }^{5}$ Adolph, E. F., and Adolph, P. E., J. Exp. Zool., 43, 105 (1925).

' Lange, C. S., J. Embryol. Exp. Morphol., 15, 125 (1966).

'Flickinger, R. A., Science, 141, 608 (1963).

${ }^{8}$ Kohl, D. M., and Flickinger, R. A., Biol. Bull., 181, 323 (1966). - Ebert, J. D., and Kaighn, M. E., in Major Problems in Developmental Biology
(edit. by Locke, M.) (Academic Press, 1966).

\section{Inflammation in Agranulocytotic Rats}

SINCE the discovery of lysosomal enzymes within polymorphonuclear leucocytes there has been an ever growing tendency to attribute to these granules an important role in acute inflammation ${ }^{1-3}$. This concept has received further support from experiments in which agents known to stabilize membranes have been shown to exert an anti-inflammatory effect ${ }^{4-6}$. In addition, it has been found that a reduced number of polymorphonuclear cells leads to reduced acute inflammatory reactions ${ }^{7}$ and Arthus type reactions ${ }^{8}$. The studies by Ward and Cochrane $^{9-12}$ on irnmunological inflammation stressing the importance of the polymorphonuclear leucocyte have often been extrapolated to non-allergic acute inflammatory states. There are, however, opposing views as to the relative importance of the polymorphonuclears in bringing about vascular changes in acute inflammation ${ }^{13}$.

We have treated twenty-four rats for 3 days with methotrexate $(2.5 \mathrm{mg} / \mathrm{kg})$ by the intraperitoneal route. The white cell count was taken for a further 10 days. Fig. 1 shows the changes that occurred in the peripheral blood 4 days after the last injection of methotrexate. The total white blood cell count was lower, as were the numbers of peripheral lymphocytes, but the dominant effect of the drug was to reduce the numbers of polymorphonuclear leucocytes virtually to zero. This effect was found to be extremely reproducible and the polymorphs usually remained at this very low level for $48 \mathrm{~h}$ after cessation of treatment, thereafter slowly increasing in number.

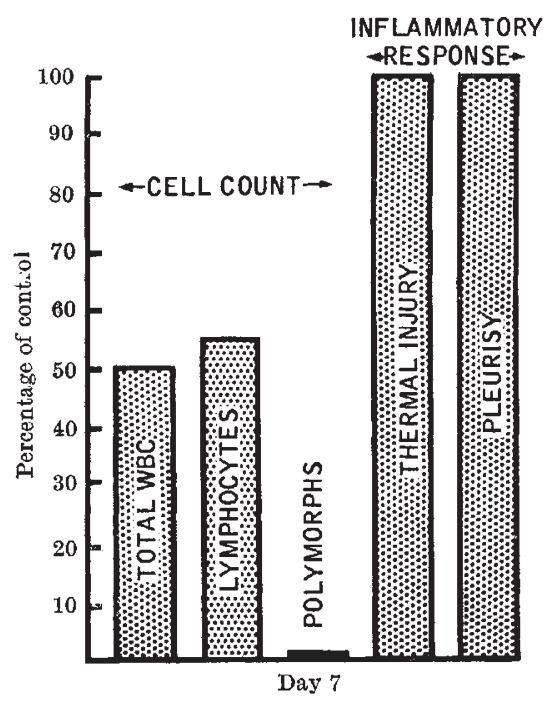

Fig. 1. Four days after methotrexate $2 \cdot 5 \mathrm{mg} / \mathrm{kg}$ for 3 days. Effect on white blood count and inflammatory response. Note normal response in
When the polymorphs were at this low level the animals were tested for their ability to respond to a standard thermal injury of $57^{\circ} \mathrm{C}$ for $27 \mathrm{~s}$. Increased vascular permeability at the site of damage was assessed by observing the degree of local leakage of trypan blue previously injected intravenously ${ }^{14}$. No differences were detectable $1 \mathrm{~h}$ after injury between twenty-four untreated and twenty-four methotrexate-treated animals. Similarly $4 \mathrm{~h}$ after the burn, when both control and treated animals were killed and the water content of the skin was determined by wet and dry weights ${ }^{14}$, there was no difference between the two groups (Fig. 1). This conclusion was amply confirmed by histology, showing intense oedema and fibrin exudation.

A second form of injury used to test the ability to produce an inflammatory response was pleurisy induced by intrapleural injection of turpentine ${ }^{15}$. It was found that animals with depleted polymorphs (twenty-four rats) yielded pleural exudates 1 and $4 \mathrm{~h}$ after injury; the volume of the exudates did not differ from normal controls (twenty-four rats, Fig. 1).

Attention has been directed recently to the possible role of complement in acute inflammation ${ }^{16}$. It seems likely that previous reports of failure to develop inflammatory vascular changes after depletion of polymorphs may have been a consequence of the methods used to destroy the leucocytes. Thus a variety of immunosuppressive agents have been shown to have non-specific anti-inflammatory actions unrelated to their effect on granulocytes, but possibly connected with the depletion of complement. In addition, various antibodies, among them antisera to lymphocytes and polymorphonuclear leucocytes, have been found to fix complement and to have non-specific anti-inflammatory properties ${ }^{17}$.

The results obtained with methotrexate do not prove that granulocytes play no part in the pathogenesis of increased vascular permeability to non-allergic inflammation. Nevertheless, they do provide evidence that these vascular changes can proceed in the absence of these cells. D. A. Willoughiy

Department of Pathology, W. G. SPECTOR

St Bartholomew's Hospital Medical College,

London.

Received May 8; revised June 4, 1968.

${ }^{1}$ Weissmann, G., Arthritis Rheum., 9, 834 (1966).

${ }^{2}$ Weissmann, G., and Thomas, L., in Bacterial Endotoxins (edit. by Landy, M., and Braun, W.), 602 (Rutgers University Press, New Brunswick, 1964).

${ }^{3}$ Glenn, E. M., Borman, B. J., and Koslowske, T. C., Biochem. Pharm., special suppl. (edit. hy Houck, J. C., and Forscher, B. K.), 27 (1968).

${ }^{4}$ Wcissmann, G., New Engl. J. Med., 273, 1084, 1143 (1965).

-Weissmann, G., and Thomas, L., Rec. Prog. Hormone Res., 20, 215 (1964).

- Persellin, K. H., and Zill, M., Arthritis Rheum., 9, 57 (1966).

7 Page, A. R., and Good, R. A., Amer. J. Pathol., 34, 645 (1958).

${ }^{8}$ Humphrey, J. H., Brit. J. Exp. Pathol., 36, 268 (1955).

'Ward, P. A., and Cochrane, C. G., J. Exp. Med., 121, 215 (1965).

${ }^{10}$ Cochrane, C. G., Weigle, W. O., and Dixon, F. L., J. Exp. Med., 110, 486 (1959).

11 Cochrane, C. G., and Aiken, B. S., J. Exp. Med., 124, 733 (1966).

${ }^{12}$ Ward, P. A., Biochem. Pharm., special suppl. (edit. by Houck, J. C., and Forscher, B. K.), 99 (1968).

${ }^{13}$ Hurley, J. V., and Spector, W. G., J. Pathol. Bact., 82, 403 (1961).

${ }^{14}$ Spector, W. G., and Willoughby, D. A., J. Pathol. Bact., 78, 121 (1959).

${ }^{15}$ Spector, W. G., and Willoughby, D. A., J. Pathol. Bact., 77, 1 (1959).

${ }_{18}$ Willoughby, D. A., Polak, L., and Turk, J. L., Nature (in the press).

17 Turk, J. L., and Willoughby, D. A., Proc. 54th Swiss Immunology Meeting (in the press).

\section{Ultraviolet Radiation and Lysosomes in Skin}

ERythema followed by scaling and increased pigmentation develops in human skin which has been exposed to moderate doses of ultraviolet radiation. Oedema, blistering and necrosis may occur after higher doses, and 